\title{
Follicular thyroid carcinoma metastasis to the facial skeleton: a systematic review
}

\author{
Varun V. Varadarajan ${ }^{1}$, Elizabeth K. Pace ${ }^{2}$, Vatsal Patel ${ }^{3}$, Raja Sawhney ${ }^{1}$, Robert J. Amdur ${ }^{4,5}$ \\ and Peter T. Dziegielewski ${ }^{1,4^{*}}$
}

\begin{abstract}
Background: Follicular thyroid carcinoma (FTC) metastasis to the facial skeleton is exceedingly rare. A case of FTC metastasizing to the mandible is presented and a systematic review of the literature describing thyroid metastasis to the facial skeleton is performed.

Case presentation: A 73-year-old female presented with metastatic FTC to the mandible and underwent total thyroidectomy, segmental mandibulectomy, bone impacted fibular free flap reconstruction, and adjuvant radioactive iodine treatment. The PubMed database was searched for literature describing thyroid cancer with facial skeleton metastasis using the key words "thyroid," "cancer," "carcinoma," "metastasis," and "malignancy" with "oral cavity," "maxilla," "mandible," "sinus," "paranasal," and "orbit." Reports that only involved the soft tissues were excluded. Systematic review revealed 59 cases of well-differentiated thyroid cancer with facial skeleton metastasis: 35 mandibular metastases $(21=\mathrm{FTC}), 6$ maxilla metastases $(2=\mathrm{FTC}), 9$ orbital metastases $(4=\mathrm{FTC})$, and 11 paranasal sinus metastases (7 = FTC). Treatment included surgery, RAl, external beam radiotherapy (XRT), or a combination of these modalities. The one, two, and five-year survival rates were $100 \%, 79 \%$, and $16 \%$, respectively.

Conclusion: Facial skeleton metastasis of FTC is a rare clinical challenge. Optimal treatment appears to include total thyroidectomy and resection of involved structures with or without adjuvant treatment.
\end{abstract}

Keywords: Follicular thyroid carcinoma, Head and neck surgery, Endocrine surgery, Thyroid neoplasm

\section{Background}

Follicular thyroid carcinoma (FTC) is the second most common thyroid carcinoma. It accounts for $\sim 10 \%$ of thyroid malignancies, with a higher occurrence in women aged 40-60 years [1]. Follicular thyroid carcinoma is known to disseminate hematogenously and metastasize in advanced cases. Distant metastases are seen in $~ 10-15 \%$ cases, with bone and lungs as preferred metastatic targets [2]. FTC metastases to the facial skeleton are exceedingly rare and present a treatment challenge.

FTC facial bone metastasis can present in the gnathic bones, the paranasal sinuses, or the orbit. Metastasis to the facial skeleton may be the first clinical sign of an

\footnotetext{
* Correspondence: Peter.Dziegielewski@ent.ufl.edu

Manuscript Presentation: This study was presented as a poster presentation at the 9th International Conference on Head and Neck Cancer on July 17, 2016 in Seattle, Washington, USA.

'Department of Otolaryngology (ENT), University of Florida, Gainesville, FL 32610, USA

${ }^{4}$ University of Florida Health Cancer Center, Gainesville, FL, USA

Full list of author information is available at the end of the article
}

underlying malignancy and clinical presentation varies depending on site of presentation as well as the primary site [3-7]. Oral cavity and maxillofacial region metastasis is uncommon and represent $1-2 \%$ of all oral and maxillofacial malignancies [3-5]. Prognoses of such lesions are assumed to be poor; however, there is a paucity of evidence to guide management of these scenarios.

In this report, a case of FTC metastasizing to the mandible is presented and a systematic review of the literature is performed. The purpose is to describe the clinical presentation, treatment, and survival outcomes of thyroid metastasis to the facial skeleton.

\section{Case presentation}

A 73-year-old female patient was evaluated at the Head and Neck Surgery Clinic at the University of Florida. Her presenting complaint was numbness and swelling of her left mandible and an intraoral lesion associated with recurrent bleeding episodes. Symptoms were present for several weeks and had initially been presumed to represent an 
episode of sialadenitis by an outside provider. Her past medical history was significant for a thyroid nodule and no chronic medical conditions. She had no history of tobacco or alcohol abuse. Physical exam demonstrated a left mandibular lesion approximately $5 \mathrm{~cm}$ in size, with fullness of the gingival mucosa overlying the mass. A mucosal punch biopsy was performed and the histology demonstrated a pyogenic granuloma.

Computerized tomography (CT) showed an aggressive mass destroying the mandibular body (Fig. 1) as well as enlarged pulmonary nodules and a lytic bone lesion at T10. Imaging also demonstrated a multinodular thyroid gland with minimal irregularity along the anterior right border. A $4.6 \mathrm{~cm}$ nodule was noted in the right thyroid lobe. Fine needle aspiration of the right thyroid mass was interpreted as a follicular lesion of undetermined significance (FLUS). Because the pathology findings were inconsistent with the CT scan, an open biopsy in the OR was performed. A mucosal incision was made over the mass and a biopsy was taken. The lesion was found to be extremely friable and bled significantly requiring ligation of the facial artery. Final pathology demonstrated FTC.

Multidisciplinary tumor board review recommended surgery followed by radioactive iodine and external beam radiotherapy. The patient underwent total thyroidectomy, neck dissection, segmental mandibulectomy, and boneimpacted fibular free flap reconstruction [6]. Intraoperative findings included a $10 \mathrm{~cm}$ thyroid mass of the right thyroid lobe that extended beneath the sternum to the innominate vein. A segment of mandible was taken from left angle to right parasymphysis, resulting in a defect from

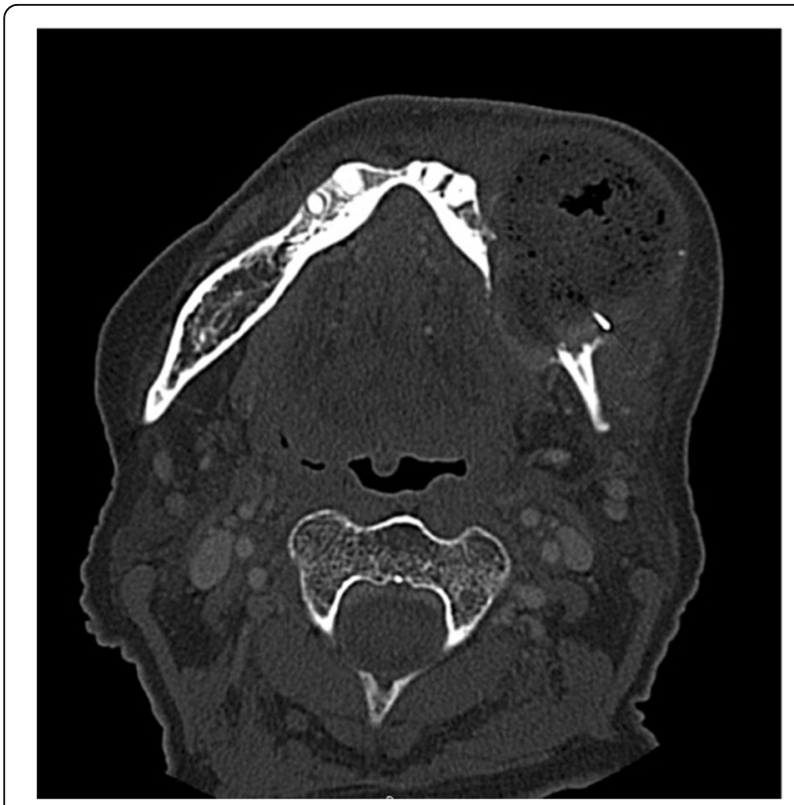

Fig. 1 Preoperative computerized tomography depicting an aggressive mass arising from the left mandible right lateral incisor to angle of mandible (Fig. 2). Reconstruction was undertaken via a right bone-impacted fibular free flap with skin paddle in addition to a $2.0 \mathrm{~mm}$ mandibular reconstruction bar. Final pathology showed mandibular metastasis of FTC with extension into the tongue and soft tissues of the neck (Fig. 3). Margins were negative. The $4.6 \mathrm{~cm}$ thyroid follicular carcinoma appeared to arise from a calcified pre-existing degenerative follicular adenoma. There was evidence of capsular invasion and extensive lymphovascular invasion. The patient underwent post-operative stereotactic body radiation to the $\mathrm{T}-10$ metastatic lesion and $200 \mathrm{mCi}$ of radioactive Iodine-131. She has been disease free for 18 months.

A systematic review of the English literature was performed using PubMed, Medline, Embase, and Scopus databases. Search terms describing FTC presenting as a metastatic lesion in the facial skeleton were compiled and implemented. These terms included: "thyroid," "cancer," "thyroid carcinoma," "thyroid cancer", "metastasis," and "malignancy" with "oral cavity," "maxilla," "mandible," "sinus," "paranasal," and "orbit." Papers were gleaned for diagnoses of well-differentiated thyroid cancer, FTC, and metastases to the facial skeleton. Reports of metastasis that only involved the soft tissues were excluded. The reports were organized by subsite: mandible, maxilla, jawbone not otherwise specified, nasal cavity or paranasal sinus, and orbit. Data points obtained from literature review included age, gender, primary oncologic diagnosis, site of metastasis, clinical presentation, treatment modality, survival outcome, and time to follow-up were obtained. Statistical analysis was performed with SPSS 23.0 software package (SPSS Inc., Chicago, IL). Survival was estimated by a Kaplan-Meier analysis to the account for censored data. Survival by treatment was analyzed and compared using the log rank test.

Literature review identified 64 studies reporting 97 cases of thyroid cancer metastasis to the facial skeleton in the English literature. All metastases were present at the time of presentation. 59 case reports specified welldifferentiated thyroid cancer as the diagnosis. Table 1 demonstrates details of these cases. 38 case reports did

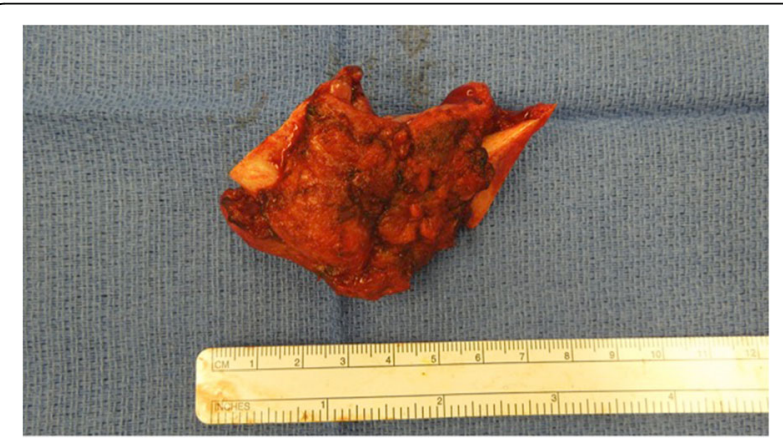

Fig. 2 Left hemimandibulectomy specimen 


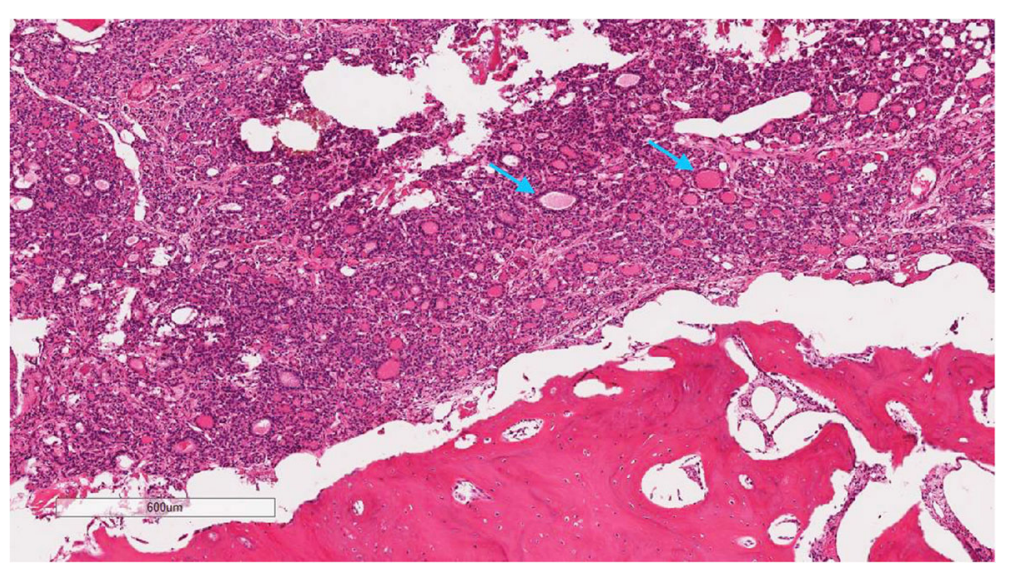

Fig. 3 Photomicrograph of hematoxylin and eosin stain at 4X power depicting tumor cells infiltrating and destroying mandibular bone. Several tumor cells are forming follicles characteristic of follicular carcinoma of the thyroid (blue arrows)

not specify the diagnosis and were not included [7-18]. The gender distribution was 9 males, 48 females, and 2 cases in which gender was not specified. While the majority of metastases were to the mandible, other craniofacial sites were also found to be involved.

Treatment varied between studies and included: Surgery with or without preoperative embolization and radioactive iodine therapy, external beam radiation (primary or adjuvant treatment), and palliative chemotherapy. 22 patients were treated with surgery as initial treatment with or without postoperative radioactive iodine or external beam radiation. 11 patients were treated with external beam radiation as primary treatment. 14 reports did not specify treatment. 4 patients were treated with palliative care; 2 of these patients received palliative chemotherapy. Cases were grouped into: a surgical arm (those treated with surgery and RAI) and a non-surgical arm. 32 studies reported survival outcome and 27 studies reported time-to-follow up. 24 patients survived treatment and 8 patients expired.

Overall survival for all patients at 2 years was $96 \%$ and at 5 years was $59 \%$. Disease specific survival at 2 years was $96 \%$ and at 5 years was $72 \%$. Patients treated with surgery and RAI versus those treated by non-surgical means were compared. There was no statistical difference in overall survival $(p=0.27)$ with the surgical group having 2 and 5 year overall survival of $100 \%$ and $71 \%$, respectively and those in the non-surgical arm having rates of $92 \%$ and $46 \%$.

Disease specific survival for all patients at 2 years was $96 \%$ and at 5 years was $72 \%$ (Fig. 4). There was a statistically significant difference in disease specific survival (DSS) between patients treated with surgery and RAI versus those treated by non-surgical means $(p=0.03)$. DSS for surgically treated patients at 2 and 5 years was $100 \%$ and for non-surgically treated patients was $92 \%$ and $46 \%$, respectively.

\section{Discussion and conclusions}

FTC is the second most common thyroid cancer, following papillary thyroid carcinoma (PTC). $10-15 \%$ of FTCs will disseminate hematogenously via angioinvasion. The most common sites of metastases include bone and lungs and less commonly brain, liver, bladder, and skin. Bone metastases can occur in the vertebral bodies followed by the pelvis, femur, skull, and ribs $[2,19]$. Treatment often involves high dose radioiodine; however, bony metastases are less likely to concentrate radioiodine, and thus, the efficacy is estimated at $55 \%$. External beam radiation therapy may be used for palliation [2].

Metastasis comprises $1 \%$ of all oral-maxillofacial malignancies. Primary sites of tumors metastatic to the facial skeleton are most commonly from the breast and lungs [20]. Thyroid malignancy represents $2 \%$ of facial skeleton metastasis [20] and $4.2-6.1 \%$ of all jaw metastases $[7,15,21] 41 \%$ of facial skeleton metastasis from thyroid cancer occurs in the mandible; $59 \%$ of these metastases are well-differentiated thyroid cancer. There have been 41 reported cases in the literature of thyroid malignancy with metastasis to the mandible of which 21 reported cases were FTC [4, 9-12, 22-47]. There have been 6 reported cases of metastasis to the maxilla; 2 were FTC [22, 48-52].

The majority of metastatic tumors to the mandible present with facial swelling and an osteolytic lesion. A rapid progression of intraoral or extraoral swelling associated with chin paresthesia and pain is not uncommon $[21,29,36,53]$. As the tumor invades oral mucosa, a granulation-like mass may form and result in significant bleeding, infection, fractures, and disturbances in swallowing and mastication [32, 40].

Isolated facial skeleton metastasis may be treated with surgical resection, radioactive iodine, external beam radiation or combinations of the three. The patient presented here was treated with a composite resection and 
Table 1 List of reported cases of thyroid cancer metastasis to the facial skeleton

\begin{tabular}{|c|c|c|c|c|c|c|c|}
\hline $\begin{array}{l}\text { Author of } \\
\text { report }\end{array}$ & $\begin{array}{l}\text { Age, } \\
\text { Gender }\end{array}$ & $\begin{array}{l}\text { Primary } \\
\text { tumor }\end{array}$ & $\begin{array}{l}\text { Site of } \\
\text { presentation }\end{array}$ & Clinical presentation & $\begin{array}{l}\text { Treatment of } \\
\text { metastases }\end{array}$ & Survival & $\begin{array}{l}\text { Time to } \\
\text { follow-up }\end{array}$ \\
\hline Agarwal et al. [26] & $45, F$ & FTC & Mandible & Facial swelling & Resection & Yes & 2 weeks \\
\hline Algahtani et al. [40] & $66, F$ & FTC & Mandible & Pathologic fracture & Resection & NR & NR \\
\hline Anil et al. [72] & $61, F$ & FTC & Mandible & Mandibular swelling & NR & NR & $N R$ \\
\hline Bhadage et al. [28] & $40, F$ & FTC & Mandible & Facial swelling & $\mathrm{NR}$, referred out & NR & NR \\
\hline Bingol et al. [27] & $33, F$ & PTC & Mandible & $\begin{array}{l}\text { Painless mass of } \\
\text { mandibular angle }\end{array}$ & Surgery, RAI & No & 5 years \\
\hline Colella et al. [75] & $50, F$ & PTC & Mandible & Pain and swelling in RMT & NR & NR & $N R$ \\
\hline Draper et al. [44] & $N R, F$ & FTC & Mandible & Ulcerated oral lesion & XRT, RAI & NR & $N R$ \\
\hline Erdag et al. [23] & $53, \mathrm{~F}$ & PTC & Mandible & Right sided facial swelling & Surgery, RAI & Yes & 2.5 years \\
\hline Essakalli et al. [41] & $50, \mathrm{~F}$ & PTC & Mandible & Painful swelling of jaw & Resection, RAI & Yes & 2 months \\
\hline Germain et al. [42] & $50, F$ & PTC & Mandible & $\begin{array}{l}\text { Jugular, carotid } \\
\text { lymphadenopathy }\end{array}$ & Resection & Yes & 17 months \\
\hline Ismail et al. [30] & $70, F$ & FTC & Mandible & Pain, "loose teeth" & NR & NR & NR \\
\hline $\begin{array}{l}\text { Kahn and } \\
\text { McCord [31] }\end{array}$ & $82, F$ & FTC & Mandible & Painful oral swelling & XRT, surgical salvage & No & 18 \\
\hline $\begin{array}{l}\text { Kumar RVK } \\
\text { et al. [32] }\end{array}$ & $58, F$ & FTC & Mandible & Painless facial swelling & $\begin{array}{l}\text { Resection, mandible } \\
\text { reconconstructive bar, } \\
\text { second stage } \\
\text { thyroidectomy }\end{array}$ & Yes & 2 years \\
\hline Lavanya et al. [29] & $76, M$ & FTC & Mandible & $\begin{array}{l}\text { Painless mandibular } \\
\text { swelling }\end{array}$ & $N R$, referred out & NR & NR \\
\hline Liu et al. [33] & $66, M$ & PTC & Mandible & Cheek mass & Resection, RAI & Yes & 3 years \\
\hline Markitziu et al. [46] & $69, F$ & PTC & Mandible & Facial swelling & XRT & Yes & 18 months \\
\hline McDaniel et al. [76] & $77, \mathrm{~F}$ & FTC & Mandible & Pain, swelling & $\begin{array}{l}\text { Resection, parotidectomy, } \\
\text { RAI }\end{array}$ & Yes & 4 years \\
\hline Meyer and Shklar [3] & $51, F$ & FTC & Mandible & NR & NR & NR & $N R$ \\
\hline \multirow{2}{*}{$\begin{array}{l}\text { Muttagi et al.: } \\
2 \text { cases [34] }\end{array}$} & NR & PTC & Mandible & NR & Surgery & NR & $N R$ \\
\hline & $N R$ & FTC & Mandible & NR & Surgery & $N R$ & $N R$ \\
\hline Nishikawa et al. [39] & $83, \mathrm{~F}$ & PDFTC & Mandible & $\begin{array}{l}\text { Painful swelling of } \\
\text { jaw and face }\end{array}$ & None & No & 19 months \\
\hline $\begin{array}{l}\text { Osguthorpe } \\
\text { and Bratton [35] }\end{array}$ & $53, M$ & FTC & Mandible & Slowly enlarging parotid mass & Resection, RAl & Yes & 3 years \\
\hline Ostrosky et al. [25] & $72, M$ & FTC & Mandible & Painful vascular lesion & Resection, iliac crest graft & NR & $N R$ \\
\hline Pasupula et al. [36] & $40, F$ & FTC & Mandible & Painful left parotid swelling & Resection & NR & NR \\
\hline Tamiolakis et al. [4] & $69, \mathrm{~F}$ & PTC & Mandible & $\begin{array}{l}\text { Facial swelling, mucosal } \\
\text { ulcerations }\end{array}$ & Inoperable & NR & $N R$ \\
\hline Tovi et al. [47] & $33, M$ & FTC & Mandible & Mimicking AVM & RAI & No & 17 days \\
\hline Vazifeh et al. [37] & $58, F$ & FTC & Mandible & Facial swelling & Resection & NR & NR \\
\hline $\begin{array}{l}\text { Vishveshwaraiah } \\
\text { et al. [38] }\end{array}$ & $56, F$ & FTC & Mandible & $\begin{array}{l}\text { Painless facial swelling, } \\
\text { face and lip paresthesia }\end{array}$ & $\mathrm{NR}$, referred out & NR & NR \\
\hline $\begin{array}{l}\text { Vural and } \\
\text { Hanna [24] }\end{array}$ & $64, \mathrm{~F}$ & FTC & Mandible & $\begin{array}{l}\text { Tender, pre-auricular } \\
\text { mass }\end{array}$ & $\begin{array}{l}\text { Resection, post op } \\
\text { iodine ablation }\end{array}$ & Yes & 6 weeks \\
\hline \multirow[t]{6}{*}{ Zandi et al. [11] } & $64, \mathrm{~F}$ & FTC & Mandible & NR & NR & NR & NR \\
\hline & $75, F$ & FTC & Mandible & NR & NR & NR & NR \\
\hline & $63, F$ & PTC & Mandible & $N R$ & NR & $N R$ & $N R$ \\
\hline & $44, \mathrm{~F}$ & PTC & Mandible & $N R$ & NR & NR & $N R$ \\
\hline & $35, F$ & PTC & Mandible & $N R$ & $N R$ & NR & $N R$ \\
\hline & $51, F$ & PTC & Mandible & NR & NR & NR & $N R$ \\
\hline
\end{tabular}


Table 1 List of reported cases of thyroid cancer metastasis to the facial skeleton (Continued)

\begin{tabular}{|c|c|c|c|c|c|c|c|}
\hline Antunes et al. [22] & $13, F$ & PTC & Maxilla & NR & NR & NR & NR \\
\hline Fatahzadeh et al. [48] & $43, \mathrm{~F}$ & PTC & Maxilla & $\begin{array}{l}\text { Hemorrhagic mass with } \\
\text { ulceration and bleeding }\end{array}$ & XRT & NR & NR \\
\hline Hefer et al. [52] & $58, M$ & FTC & Maxilla & Left hard palate pain & Resection & Yes & 2 years \\
\hline Kumar CS et al. [51] & $31, F$ & FTC & Maxilla & Painful swelling, mobile teeth & RAl & Yes & 7 years \\
\hline Nikitakis et al. [49] & $63, M$ & PTC & Maxilla & $\begin{array}{l}\text { Painful swelling of right } \\
\text { posterior maxilla }\end{array}$ & $\begin{array}{l}\text { XRT, palliative } \\
\text { chemotherapy }\end{array}$ & Yes & 2 years \\
\hline Slim et al. [50] & $67, F$ & PTC & Maxilla, zygoma & Painless malar swelling & $\begin{array}{l}\text { Resection, postoperative } \\
\text { iodine ablation }\end{array}$ & Yes & NR \\
\hline Cinberg et al. [64] & $80, F$ & FTC & Maxillary sinus & Epistaxis & RAl & NR & NR \\
\hline Altinay et al. [69] & $68, F$ & FTC & $\begin{array}{l}\text { Nasal Cavity, orbit, } \\
\text { skull base }\end{array}$ & $\begin{array}{l}\text { Left eye puffiness, proptosis, } \\
\text { vision Loss, facial numbness }\end{array}$ & XRT & Yes & 1 month \\
\hline Malhotra et al. [60] & $55, \mathrm{~F}$ & FTC & $\begin{array}{l}\text { Orbit (Anterolateral } \\
\text { orbit) }\end{array}$ & Proptosis, vision Loss & Resection, RAI & NR & NR \\
\hline $\begin{array}{l}\text { Rocha Filho } \\
\text { et al. [57] }\end{array}$ & $66, F$ & PTC & Orbit (Frontal bone) & Frontal bone mass & Palliative chemo & Yes & NR \\
\hline $\begin{array}{l}\text { Bernstein- } \\
\text { Lipschitz et al. [55] }\end{array}$ & $56, F$ & FTC & $\begin{array}{l}\text { Orbit (Lacrimal fossa, } \\
\text { orbital roof) }\end{array}$ & Diplopia, ptosis, orbital Pain & Resection & NR & $N R$ \\
\hline Shyla et al. [54] & $70, F$ & PTC & $\begin{array}{l}\text { Orbit (Posterior orbit } \\
\text { extending to ethmoid } \\
\text { bone) }\end{array}$ & Vision loss & Resection, XRT & Yes & NR \\
\hline $\begin{array}{l}\text { Boughattas } \\
\text { et al. [56] }\end{array}$ & $25, F$ & PTC & Orbit (Supraorbital) & Asymptomatic & NR & NR & NR \\
\hline Daumerie et al. [58] & $59, \mathrm{~F}$ & PTC & $\begin{array}{l}\text { Orbit (Supratemporal } \\
\text { quadrant) }\end{array}$ & $\begin{array}{l}\text { Left upper eyelid swelling, } \\
\text { exophthalmos }\end{array}$ & RAI & Yes & 2 months \\
\hline $\begin{array}{l}\text { Pagsisihan } \\
\text { et al. [59] }\end{array}$ & $49, F$ & PTC & Orbit (Supraorbital) & Supraorbital mass & RAl & Yes & 6 months \\
\hline Argibay-Vasquez [77] & $53, \mathrm{~F}$ & PTC & Sphenoid & $\begin{array}{l}\text { Headache, paresthesia in } \\
\text { the right eye region, left } \\
\text { monocular diplopia }\end{array}$ & $\begin{array}{l}\text { RAI, subtototal resection, } \\
\text { XRT, RAI }\end{array}$ & Yes & 3 years \\
\hline Yamasoba et al. [67] & $34, \mathrm{~F}$ & FTC & $\begin{array}{l}\text { Ethmoid, sphenoid, } \\
\text { maxillary, intracranial }\end{array}$ & $\begin{array}{l}\text { Cheek hypoesthesia, } \\
\text { hearing Loss }\end{array}$ & Embolization, resection & Yes & $N R$ \\
\hline Renner et al. [65] & $61, \mathrm{~F}$ & FTC & Sphenoid sinus & Epistaxis, anosmia, visual loss & RAI, XRT & Yes & 5 months \\
\hline Barrs et al. [63] & $54, \mathrm{~F}$ & FTC & Sphenoid sinus, orbit & Visual loss & RAI, XRT & No & 5 years \\
\hline Altman et al. [68] & $81, M$ & FTC & $\begin{array}{l}\text { Sphenoid, ethmoid, } \\
\text { skull base }\end{array}$ & Headache & XRT & No & 1 year \\
\hline Freeman et al. [78] & $50, M$ & PTC & Sphenoid, ethmoid & $\begin{array}{l}\text { Facial pain, proptosis of the } \\
\text { left globe, left horner's } \\
\text { syndrome }\end{array}$ & XRT, RAI & Yes & 1 year \\
\hline Madronio et al. [79] & $53, \mathrm{~F}$ & PTC & Sphenoid, ethmoid & $\begin{array}{l}\text { Headache, galactorrhea, } \\
\text { vision loss }\end{array}$ & Surgical debulking & Yes & 13 months \\
\hline $\begin{array}{l}\text { Cumberworth } \\
\text { et al. [66] }\end{array}$ & $74, F$ & FTC & $\begin{array}{l}\text { Sphenoid, frontal, } \\
\text { ethmoid, and } \\
\text { maxillary sinuses }\end{array}$ & Nasal obstruction & None & No & $\begin{array}{l}1 \text { week after } \\
\text { diagnosis }\end{array}$ \\
\hline
\end{tabular}

FTC Follicular Thyroid Carcinoma, NR not reported, PTC Papillary Thyroid Carcinoma, RAI Radioactive lodine Therapy, XRT External Beam Radiation Therapy

radioactive iodine. Her defect was reconstructed with a bone-impacted osteocutaneous fibula free flap. Followup CT scanning demonstrated that the neo-mandible retained a dense bone stock from the bone impaction. Free flap reconstruction for metastatic thyroid cancer to the mandible has only been reported once in the literature [42]. The current case is the first report of a boneimpacted fibular free flap used in this scenario.
Metastatic thyroid carcinomas are also reported in the orbit and paranasal sinuses. 9 cases have been described in the bony orbit; 4 of these were FTC [16, 54-61]. Surgical debulking of the metastatic foci may restore vision in cases of sudden onset vision loss; radioiodine treatment has also been documented as treatment for tumors that uptake iodine. External beam radiation can also be an option. There are 17 reported cases of thyroid malignancy 


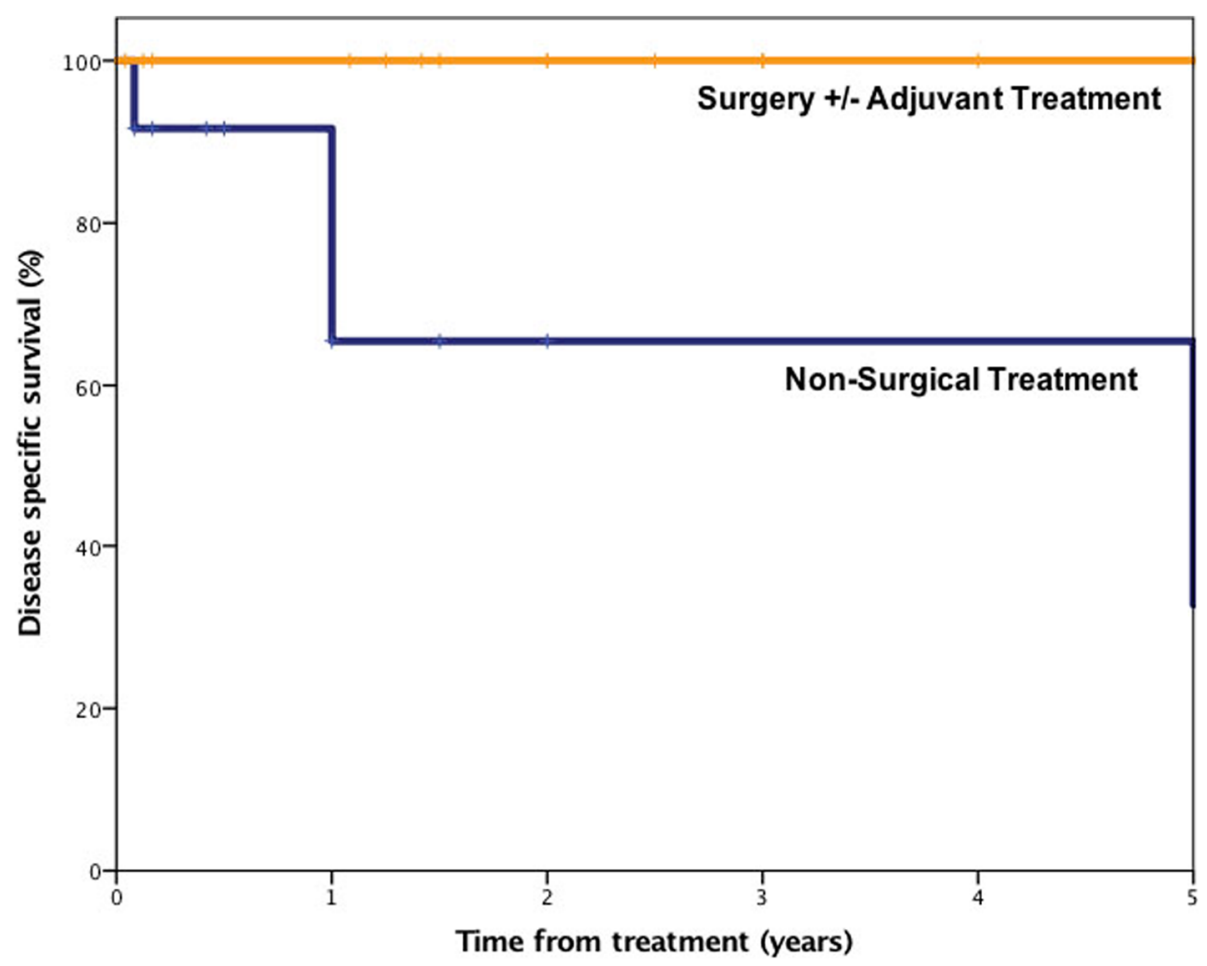

Fig. 4 Disease specific survival for patients with well-differentiated thyroid cancer metastatic to the facial skeleton treated with surgery as initial treatment with adjuvant radioactive iodine therapy versus non-surgical treatment (external beam radiation)

presenting as a paranasal sinus mass (14.1\%); 7 of these cases were FTC $[8,13,14,17,18,62-69]$. Two cases presented simultaneously in the paranasal sinus and the bony orbit [63, 69]. Clinical manifestations include epistaxis, nasal obstruction, visual disturbances, and facial or intraoral swelling [70, 71]. The maxillary sinus is the most commonly involved sinus followed by the sphenoid sinus, ethmoid, and frontal sinus [70, 72]. The vertebral venous plexus, which allows retrograde spread of tumor emboli, could explain the etiology of paranasal sinus and orbital metastasis [71, 73]. Craniofacial resection or debulking with or without preoperative vascular embolization can be considered, however, the proximity of the metastatic tumor to the skull base may preclude surgical extirpation $[59,67,69]$. Radioiodine therapy, external beam radiation, chemotherapy, or palliative therapy can be considered in these patients [57, 59, 68, 74].

Survival analysis suggests that surgical resection of involved craniofacial structures with or without adjuvant treatment is the optimal treatment for FTC metastatic to the facial bones. Given the rarity of the condition, the sample size is limited; however, survival analysis demonstrated convincing statistically significant advantages with surgical resection. Treatment plans should be formulated with a multidisciplinary team involving surgical oncology, radiology, pathology, endocrinology, medical oncology, radiation oncology, and possibly palliative care.
In conclusion, facial skeleton metastasis of FTC is a rare clinical challenge. If feasible, surgical-based treatment options offer the best survival outcomes. When mandibular defects are present, reconstruction with a bone impacted fibular free flap may provide a reconstruction with a robust bone stock.

\section{Abbreviations}

CT: Computerized tomography; FTC: Follicular thyroid carcinoma; NR: Not reported; PTC: Papillary thyroid carcinoma; RAl: Radioactive iodine therapy; XRT: External beam radiation therapy

\section{Acknowledgements}

The authors have no acknowledgements.

Funding

The authors of this study declare no sources of funding for this study.

\section{Availability of data and materials}

All data generated or analyzed during this study are included in this published article.

\section{Authors' contribution}

W participated in the design of the study, data collection, participated in statistical analysis, and drafted the manuscript. EP participated in data collection, statistical analysis, and in drafting the manuscript. VP participated in data collection, histopathology interpretation, and drafting the manuscript. RS participated in the design of the study and in conceiving the study. RA participated in critically revising the manuscript for important intellectual content. PD conceived and designed the study, performed statistical analysis, and revised the manuscript critically for important intellectual content. All authors read and approved the final manuscript. 


\section{Authors' information}

$W$ is an Otolaryngology - Head and Neck Surgery resident physician at the University of Florida in Gainesville, Florida. EP is a senior medical student at the University of Florida College of Medicine in Gainesville, Florida. VP is a Pathology resident physician at the University of Florida in Gainesville, Florida. RS is an Assistant Professor in the University of Florida Department of Otolaryngology - Division of Facial Plastic Surgery in Gainesville, Florida. RA is a Professor in the University of Florida Department of Radiation Oncology. PD is an Assistant Professor at the University of Florida Department of Otolaryngology and Chief of the Division of Head and Neck Oncologic Surgery in Gainesville, Florida.

\section{Competing interests}

The authors of this study manuscript declare that they have no competing interests.

\section{Consent for publication}

Written informed consent was obtained from the patient for publication of this Case report and any accompanying images.

\section{Ethics approval and consent to participate}

Ethics approval was not necessary for this study and manuscript due to the type of study design (Case Report, Literature Review). All patient data and photographs are de-identified.

\section{Publisher's Note}

Springer Nature remains neutral with regard to jurisdictional claims in published maps and institutional affiliations.

\section{Author details}

'Department of Otolaryngology (ENT), University of Florida, Gainesville, FL 32610, USA. ${ }^{2}$ University of Florida College of Medicine, Gainesville, FL, USA. ${ }^{3}$ Department of Pathology, University of Florida, Gainesville, FL, USA. ${ }^{4}$ University of Florida Health Cancer Center, Gainesville, FL, USA. ${ }^{5}$ Department of Radiology, University of Florida, Gainesville, FL, USA.

Received: 30 November 2016 Accepted: 15 March 2017 Published online: 28 March 2017

\section{References}

1. D'Avanzo A, Treseler P, Ituarte PHG, Wong M, Streja L, Greenspan FS, et al. Follicular thyroid carcinoma: histology and prognosis. Cancer. 2004;100:1123-9.

2. McHenry CR, Phitayakorn R. Follicular adenoma and carcinoma of the thyroid gland. Oncologist. 2011;16:585-93.

3. Meyer I, Shklar G. Malignant tumors metastatic to mouth and jaws. Oral Surg Oral Med Oral Pathol. 1965;20:350-62.

4. Tamiolakis D, Tsamis I, Thomaidis V, Lambropoulou M, Alexiadis G, Venizelos I, et al. Jaw bone metastases: four cases. Acta Dermatovenerol Alp Panonica Adriat. 2007:16:21-5.

5. Brucoli M, Arcuri F, Stellin L, Benech A. Zygomatic metastasis from breast cancer. J. Craniofac. Surg. 2010;21:2012-4.

6. Dziegielewski PT, Mlynarek AM, Harris JR, Hrdlicka A, Barber B, Al-Qahtani K, et al. Bone impacted fibular free flap: a novel technique to increase bone density for dental implantation in osseous reconstruction. Head Neck 2013

7. Batsakis J. Tumors of the head and neck: clinical and pathological considerations. 2nd ed. Baltimore: Williams \& Wilkins; 1979.

8. DeVincentiis I. Sulle metastasi del cancro tiroideo di interesse otorhinolayngoiatrico. Ann di Laringol Otol Rinol Farinologia. 1959:33:39-48.

9. Kaveri H. VA Punnya TA. Metastatic thyroid carcinoma to the mandible. J Oral Maxillofac Path. 2007;11:32-4.

10. Mahtar M, Kadiri F, Detsouli M, Raji A, Idrissi Chekkoury A, Benchakroun Y. [Mandibular metastasis revealing thyroid carcinoma. Two cases]. Rev. Stomatol. Chir. Maxillofac. 2002:103:120-3.

11. Zandi M, Jafari M, Isapour M, Jafari AA. Mandibular metastasis in a patient with undiscovered synchronous thyroid and prostate cancer: a diagnostic dilemma. J Oral Maxillofac Pathol. 2014;18:449-52.

12. Ripp GA, Wendth AJ, Vitale P. Metastatic thyroid carcinoma of the mandible mimicking an arteriovenous malformation. J Oral Surg. 1977;35:743-5

13. Bataille R, Schuhmann C, Rolland J. Sinusal metastasis from a thyroid epithelioma. Rev Stomatol Chir Maxillofac. 72:129-31.
14. Auriti F. Adenoma struttura tiroidea del setto nasale. Arch Ital di Laryngol. 1921:4:120-7.

15. Hirshberg A, Shnaiderman-Shapiro A, Kaplan I, Berger R. Metastatic tumours to the oral cavity - pathogenesis and analysis of 673 cases. Oral Oncol. 2008:44:743-52

16. Betharia SM. Metastatic orbital carcinoma of thyroid. Indian J Ophthalmol. 33:191-3.

17. Chang G, Weber A, Pappanikou A. X-ray study of the month. Metastatic carcinoma of the thyroid to the sphenoid sinus. Ann Otol RhinolLaryngol. 1983;92:309-10.

18. Von Eiselberg A. Uber knochen-metastasen des schilddrusen krebses verhandl. Deutsch Gesellchraft fur Chir. 1893;22

19. Cooper DS, Doherty GM, Haugen BR, Hauger BR, Kloos RT, Lee SL, et al. Revised American Thyroid Association management guidelines for patients with thyroid nodules and differentiated thyroid cancer. Thyroid. 2009;19:1167-214.

20. Friedrich RE, Abadi M. Distant metastases and malignant cellular neoplasms encountered in the oral and maxillofacial region: analysis of 92 patients treated at a single institution. Anticancer Res. 2010;30:1843-8.

21. Hirshberg A, Berger R, Allon I, Kaplan I. Metastatic tumors to the jaws and mouth. Head Neck Pathol. 2014;8:463-74.

22. Antunes AA, Antunes AP. Gnathic bone metastasis: a retrospective study of 10 cases. Braz J Otorhinolaryngol. 2008;74:561-5.

23. Erdag T, Bilgen C, Ceryan K. Metastatic thyroid carcinoma of the mandibule. Rev Laryngol Otol Rhinol (Bord). 1999;120:31-4.

24. Vural E, Hanna E. Metastatic follicular thyroid carcinoma to the mandible: a case report and review of the literature. Am J Otolaryngol. 1998;19:198-202.

25. Ostrosky A, Mareso EA, Klurfan FJ, Gonzalez MJ. Mandibular metastasis of follicular thyroid carcinoma. Case report Med Oral. 2003;8:224-7.

26. Agarwal A, Mishra SK, Jain M. Follicular thyroid carcinoma with metastasis to the mandible. J Indian Med Assoc. 1998:96:354-5.

27. Bingol UA, Cinar C, Cetinkale O. Mandibular metastases of papillary thyroid carcinoma treated by hemimandibulectomy and costochondral rib graft. Plast Reconstr surgery Glob open. 2015;3:e305

28. Bhadage CJ, Vaishampayan S, Umarji H. Mandibular metastasis in a patient with follicular carcinoma of thyroid. Contemp Clin Dent. 2012;3:212-4

29. Lavanya C, Ranganathan K, Veerabahu M. Mandibular metastasis of thyroid carcinoma: a case report. J Clin Diagn Res. 2014;8:ZD15-6.

30. Ismail S. Bin, Abraham MT, Zaini ZB, Yaacob H Bin. Zain RB Case report Metastatic follicular thyroid carcinoma to the mandible : a case report. 2009;3:3-5.

31. Kahn MA. Mccord PT. Metastatic Thyroid Carcinoma of the Mandible : Case Report. 1989:1314-6.

32. Kumar RVK, Chakravarthy C, Sekhar GR, Devireddy SK, Kumaravelu C, Kare A. Metastatic thyroid carcinoma presenting as Hypervascular lesion of the mandible: a case report and review of literature. J Oral Maxillofac Surg. 2010;68:2613-6. Available from: http://linkinghub.elsevier.com/retrieve/pii/ S027823910901934X

33. Liu L, Venkataraman G, Salhadar A. Follicular variant of papillary thyroid carcinoma with unusual late metastasis to the mandible and the scapula. Pathol Int. 2007:57:296-8. Available from: http://doi.wiley.com/10.1111/j. 1440-1827.2007.02092.x

34. Muttagi S, D'Cruz A, Chaukar D, Singh B, Chaturvedi P, Kane S, et al. Metastatic tumors to the jaw bones: retrospective analysis from an Indian tertiary referral center. Indian J Cancer 2011;48:234. Available from: http:// www.indianjcancer.com/text.asp?2011/48/2/234/82894

35. Osguthorpe JD, Bratton JR. Occult thyroid carcinoma appearing as a single mandibular metastasis. Otolaryngol. Head Neck Surg. 1982;90:674-5.

36. Pasupula AP, Dorankula SPR, Thokala MR, Kumar MP. Metastatic follicular thyroid carcinoma to the mandible. Indian J. Dent. Res. 23:843.

37. Vazifeh Mostaan L, Irani S, Rajati M, Memar B. Mandibular metastasis from follicular thyroid carcinoma: a rare case after twelve years. Arch Iran Med. 2013;16:557-9.

38. Vishveshwaraiah PM, Mukunda A, Laxminarayana KK, Kasim K. Metastatic follicular thyroid carcinoma to the body of the mandible mimicking an odontogenic tumor. J Cancer Res Ther. 9:320-3.

39. Nishikawa H, Nakashiro K, Sumida T, Sugita A, Hamakawa H. Mandibular osteoblastic metastasis of poorly differentiated carcinoma of the thyroid gland. Int. J. Oral Maxillofac. Surg. [internet]. 2010:39:301-4. Available from. http://www.ncbi.nlm.nih.gov/pubmed/19942407

40. Algahtani M, Alqudah M, Alshehri S, Binahmed A, Sándor GKB. Pathologic fracture of the mandible caused by metastatic follicular thyroid carcinoma. J Can Dent Assoc. 2009·75:457-60. Available from: http.//www.ncbi.nlm.nih. gov/pubmed/19627656 
41. Essakalli L, Jazouli N, Kzadri M. [Mandibular metastasis disclosing a papillary carcinoma of the thyroid gland]. Rev. Stomatol. Chir. Maxillofac. 1994;95:351-4.

42. Germain MA, Marandas P, Leridant AM, Domenge C, Julieron M, Schlumberger $\mathrm{M}$, et al. Isolated mandibular metastasis of cancer of the thyroid. Mandibulectomy and reconstruction using a free vascularized peroneal graft. Rev Stomatol Chir Maxillofac. 1998;98:371-4

43. Sirichitra $\vee$. Follicular thyroid carcinoma metastasizing to the mandible (case report). J Dent Assoc Thai. 1981;31:75-83.

44. Draper BW, Precious DS, Priddy RW, Byrd DL. Clinicopathological conference. Case 29, part 2. Follicular thyroid carcinoma metastatic to the mandible. J. Oral Surg. 1979;37:736-9.

45. Parichatikanond P, Parichatikanond P, Damrongvadha P, Kompairoj C, Chaovanapricha K. Jaw metastasis from follicular carcinoma of thyroid gland simulating ameloblastoma. J Med Assoc Thail. 1984;67:362-7.

46. Markitziu A, Fisher D, Marmary Y. Thyroid papillary carcinoma presenting as jaw and parotid gland metastases. Int J Oral Maxillofac Surg. 1986;15:648-53.

47. Tovi F, Leiberman A, Hirsch M. Uncommon clinical manifestations in a case of thyroid carcinoma. Head Neck Surg. 6:974-7.

48. Fatahzadeh M, Subramanian MSDG. Singer SR. Metastatic papillary thyroid carcinoma to maxilla : A rare case. 2015;46:431-5.

49. Nikitakis NG, Polymeri A, Polymeris A, Sklavounou A. Metastatic papillary thyroid carcinoma to the maxilla: case report and literature review. Head Neck Pathol. 2012;6:216-23. Available from: http://www.pubmedcentral.nih. gov/articlerender.fcgi?artid=3370027\&tool=pmcentrez\&rendertype=abstract

50. Slim I, Mhiri A, Meddeb I, Goucha A, Gritli S, Ben Slimene MF. Malar bone metastasis revealing a papillary thyroid carcinoma. Case Rep Otolaryngol. 2012;2012:795686.

51. Kumar CS, Shanmugam D, Venkatapathy R, Munshi MAI. Metastatic follicular carcinoma of thyroid in maxilla. Dent Res J (Isfahan). 2013;10:817-9.

52. Hefer T, Manor R, Zvi Joachims H, Groisman GM, Peled M, Gov-Ari E, et al. Metastatic follicular thyroid carcinoma to the maxilla. J Laryngol Otol. 1998;112:69-72.

53. Murillo J, Bagan JV, Hens E, Diaz JM, Leopoldo M. Tumors metastasizing to the oral cavity: a study of 16 cases. J Oral Maxillofac Surg. 2013;71:1545-51. Available from: http://www.ncbi.n/m.nih.gov/pubmed/23800673

54. Shyla PR, Nair RM, Somanathan T. Rare case of orbital tumor. Indian J. Otolaryngol. Head Neck Surg. 2007;59:174-5. Available from: http://www. ncbi.nlm.nih.gov/pubmed/19727568

55. Bernstein-Lipschitz L, Lahav M, Chen V, Gutman I, Gal R, Lipschitz M. Metastatic thyroid carcinoma masquerading as lacrimal gland tumor. Graefes Arch Clin Exp Ophthalmol. 1990;228:112-5.

56. Boughattas S, Chatti K, Degdegui M, Bouslama Z, Elaouni C. Uncommon case of orbital metastasis secondary to papillary thyroid carcinoma. Thyroid. 2005;15: 1311-2. Available from: http://www.ncbi.nlm.nih.gov/pubmed/16356099

57. Rocha Filho FD, Lima GG, Ferreira FV, de A, Lima MG, Hissa MN. Orbital metastasis as primary clinical manifestation of thyroid carcinoma-case report and literature review. Arq. Bras. Endocrinol. Metabol. 2008;52:1497500. Available from: http://www.ncbi.nlm.nih.gov/pubmed/19197459

58. Daumerie C, De Potter P, Godfraind C, Rahier J, Jamar F, Squifflet JP. Orbital metastasis as primary manifestation of thyroid carcinoma. Thyroid. 2000;10:189-92

59. Pagsisihan DA, Aguilar AHI, Maningat MPDD. Orbital metastasis as initial manifestation of a widespread papillary thyroid microcarcinoma. BMJ Case Rep. 2015;2015 Available from: http://www.ncbi.nlm.nih.gov/pubmed/ 25819821

60. Malhotra G, Upadhye TS, Menon S, Asopa RV, Laskar SG, Pawar S, et al. Unilateral proptosis due to orbital metastasis as a presenting clinical manifestation of carcinoma of the thyroid. Clin Nucl Med. 2010;35:362-5. Available from: http://www.ncbi.nlm.nih.gov/pubmed/20395717

61. Tijl J, Koornneef L, Eijpe A, Thomas L, Gonzalez DG, Veenhof C. Metastatic tumors to the orbit-management and prognosis. Graefes Arch Clin Exp Ophthalmol. 1992;230:527-30.

62. Harmer L. Schilddrusenmetastase in der Nasenhohle. Weiner Klin Wochenschrift 1899;23:628-31

63. Barrs DM, McDonald TJ, Whisnant JP. Metastatic tumors to the sphenoid sinus. Laryngoscope. 1979;89:1239-43.

64. Cinberg JZ, Terrife D. Follicular adenocarcinoma of the thyroid in the maxillary sinus. Otolaryngol Head Neck Surg. 1979;88:157-8.

65. Renner GJ, Davis WE, Templer JW. Metastasis of thyroid carcinoma to the paranasal sinuses. Otolaryngol - Head Neck Surg. 1984;92:233-7.

66. Cumberworth VL, Ohri A, Morrissey G, Stirling R. Late sino-nasal metastasis from follicular thyroid carcinoma. J Laryngol Otol. 1994;108:1010-1.
67. Yamasoba T, Kikuchi S, Sugasawa M, Higo R, Sasaki T. Occult follicular carcinoma metastasizing to the sinonasal tract. ORL J Otorhinolaryngol Relat Spec. 56:239-43.

68. Altman KW, Mirza N, Philippe L. Metastatic follicular thyroid carcinoma to the paranasal sinuses: a case report and review. J Laryngol Otol. 1997;111:647-51.

69. Altinay S, Taskin U, Aydin S, Oktay MF, Ozen A, Ergul N. Metastatic follicular thyroid carcinoma masquerading as olfactory Neuroblastoma: with SkullBase, cranium, Paranasal sinus, lung, and diffuse bone metastases. J Craniofac Surg. 2015;26:E3-6.

70. Prescher A, Brors D. Metastases to the paranasal sinuses: case report and review of the literature. Laryngorhinootologie. 2001;80:583-94. Available from: http://www.ncbi.nlm.nih.gov/pubmed/11602931

71. Krishnamurthy A, Vaidhyanathan A, Krishna KR. Metastasis of follicular thyroid carcinoma to the maxillary sinus. Indian J Nucl Med. 2010;25:168-70. Available from: http://www.ncbi.nlm.nih.gov/pubmed/21712913

72. Anil S, Lal PM, Gill DS, Beena VT. Metastasis of thyroid carcinoma to the mandible. Case report. Aust Dent J. 1999;44(1):56-57.

73. Nahum AM, Bailey BJ. Malignant tumors metastatic to the Paranasal sinuses: case report and review of the literature. Laryngoscope. 1963;73:942-53. Available from: http://www.ncbi.nlm.nih.gov/pubmed/14043146

74. López F, Devaney KO, Hanna EY, Rinaldo A, Ferlito A. Metastases to nasal cavity and paranasal sinuses. Head Neck. 2016:38(12):1847-54.

75. Colella G, Capone R, Cappabianca S. Mandibular metastasis from papillary thyroid carcinoma-a case report. Tumori. 2003:89(4):452-454

76. McDaniel RK, Luna MA, Stimson PG. Metastatic tumors in the jaws. Oral Surgery, Pral Med Oral Pathol. 1971;31(3):380-386.

77. Argibay Vázquez S, Lancha Hernández C, Martínez Muñiz A. Metastases in the sphenoidal sinus in a patient with papillary thyroid cancer. Clin Transl Oncol. 2005;7(7):324-327.

78. Freeman JL, Gershon A, Liavaag PG, Walfish PG. Papillary thyroid carcinoma metastasizing to the sphenoid-ethmoid sinuses and skull base. Thyroid. 1996;6(1):59-61.

79. Madronio EB, Lantion-Ang FL. The tale of two tumours: an undiagnosed case of papillary thyroid carcinoma. BMJ Case Rep. 2011;2011:1-6.

\section{Submit your next manuscript to BioMed Central and we will help you at every step:}

- We accept pre-submission inquiries

- Our selector tool helps you to find the most relevant journal

- We provide round the clock customer support

- Convenient online submission

- Thorough peer review

- Inclusion in PubMed and all major indexing services

- Maximum visibility for your research

Submit your manuscript at www.biomedcentral.com/submit
) Biomed Central 